\title{
Macro-environmental Regulation and Corporate Financial Constraints: A Quasi-Natural Experiment of China's Low-Carbon City Pilot
}

\author{
Qi Liu ${ }^{1}$, Yongyu Gui ${ }^{2}$, Wei Wang ${ }^{3}$ (D) ${ }^{\text {, }}$, Hua Wang ${ }^{4}$ (D) \\ ${ }^{1}$ Network Information Center, Guangxi Normal University, China, ${ }^{2}$ Department of Financial, Hubei Power Exchange Center Ltd, China, ${ }^{3}$ School of \\ Economics and Management, Guangxi Normal University, China, ${ }^{4}$ School of Accounting, Zhongnan University of Economics and Law, China \\ Keywords: low-carbon city, Corporate financial constraints, Macro-environmental regulation, JEL Q53 Q58 G32 \\ https://doi.org/10.46557/001c.30059
}

\section{Energy RESEARCH LETTERS}

Vol. 3, Issue 4, 2022

\begin{abstract}
This paper examines the impact of macro-environmental regulations on corporate financial constraints, using the shocks of China's low-carbon city pilots and panel data on Chinese A-share listed companies from 2009 to 2018. We find that low-carbon city pilot regulation lessens the intensity of corporate financial constraints. We further find that this negative relation is more significant for state-owned enterprises and manufacturing enterprises.
\end{abstract}

\section{Introduction}

In this paper, we use China's low-carbon city pilots as exogenous shocks to examine whether and how macro-environmental regulation influences the financial behavior of micro-enterprises. Our hypothesis is that the low-carbon city pilot reduces the intensity of corporate financial constraints. This proposed relation is motivated by the theory of credit rationing proposed by Stiglitz \& Weiss (1981). Accordingly, we speculate that environmental regulation increases the likelihood of firms in low-carbon cities obtaining credit guarantees, such that banks are subjectively more willing to provide them loans.

In China's attempt to meet its 2030 target in curbing greenhouse gas emissions, the National Development and Reform Commission launched low-carbon provincial and urban pilot projects in 2012 and 2017 to include six provinces, 80 cities, and one region. ${ }^{1}$ In 2017 , the China Securities Regulatory Commission stated that companies that committed administrative or other crimes related to environmental protection during the most recent three years would not be allowed to conduct initial public offerings, indicating that environmental regulation will affect firms' financing activities. The literature shows that firms supporting such policies have a higher likelihood of obtaining long-term loans, government subsidies, and tax reductions
(Aghion et al., 2015; D. Chen et al., 2017; Eaton \& Grossman, 1986; Kollmann et al., 2012). Therefore, this hypothesis test is important. Moreover, we test whether this relation is affected by firm heterogeneity, namely, between state-owned enterprises (SOEs) and non-SOEs and between manufacturing and other industries.

We use low-carbon city pilot shocks and panel data on China's A-share listed companies from 2009 to 2018 to examine the influence of macro-environmental regulations on corporate financial constraints. We employ a differencein-differences (DID) methodology to overcome endogeneity concerns attributed to low-carbon city pilot non-random selection, reverse causality, and omitted variables. We find that low-carbon city pilot policies lessen the intensity of corporate financial constraints. These results hold for robustness tests that address endogeneity issues stemming from firm characteristics, such as propensity score matching (PSM) with DID. We further find that the negative relation between the low-carbon city pilots and corporate financial constraints are more significant among SOEs and manufacturing enterprises.

With these findings, this study makes two contributions to the literature. First, it enriches the literature on the impact of macro-environmental regulation on micro-corporate financial behavior. This literature primarily discusses

\footnotetext{
a Corresponding author:

Email: wangwei@mailbox.gxnu.edu.cn

Address: No.15, Yucai Road, Qixing District, Guilin, Guangxi Province, China, 541004
}

1 The first pilot includes the provinces and cities of Guangdong, Liaoning, Hubei, Shaanxi, Yunnan, Tianjin, Chongqing, Shenzhen, Xiamen, Hangzhou, Nanchang, Guiyang, and Baoding; and the second pilot includes the provinces and cities of Beijing, Shanghai, Shijiazhuang, Qinhuangdao, Jincheng, Hulun Buir, Huai’an, Zhenjiang, Jilin, Suzhou, Ningbo, Wenzhou, Chizhou, Nanping, Jingdezhen, Ganzhou, Qingdao, Jiyuan, Wuhan, Guangzhou, Guilin, Guangyuan, Zunyi, Kunming, Yan’an, Jinchang, Wulumuqi, and Hainan. 
the influence of low-carbon city pilot regulation on Chinese cities' carbon emissions (Zhang, 2020), environmental pollution governance (Song et al., 2019), and green production factors (Cheng et al., 2019) based on macro research. However, there is scant literature on the impacts of macro-environmental regulation on the financial constraints of micro-enterprises. Second, this article provides evidence on financial constraints from the perspective of macro-environmental regulation. Following the literature, we examine the relation between low-carbon city pilot policy and corporate financial constraints.

\section{Sample, Model, and Variables}

We adopt China's Shanghai and Shenzhen Stock Exchange A-share listed companies from 2009 to 2018 as the initial research sample, for a total of 27,134 annual observations. We exclude 529 annual observations of financial firms, 774 annual observations of listed companies with the ST or *ST label, 546 annual observations of firms whose debt is greater than total assets, and 2,281 annual observations of firms missing or with abnormal values of major variables. We obtain a final sample of 23,004 annual firm observations.

This paper aims to examine whether low-carbon city pilot regulation alleviates corporate financial constraints. The DID estimation method is regarded as an increasingly popular and effective way to assess the impact of regulation shocks. Therefore, we estimate average treatment/causal effects by the differences in outcome parameters between the treatment group (i.e., low-carbon pilot cities) and the control group (i.e., non-pilot cities) before and after the implementation of regulation, to identify the net effect of regulation shocks after eliminating unobservable and timevarying endogenous factors. We follow Cui et al. (2018) and Cheng et al. (2019) and construct the following regression model:

$$
\begin{aligned}
S A_{i t}= & \alpha_{0}+\alpha_{1} \text { Pilotreat }_{i}+\alpha_{2} \text { Post }_{i t} \\
& +\alpha_{3} \text { Pilotreat }_{i} * \text { Post }_{i t}+C V s_{i t}+\varphi_{t} \\
& +\omega_{i}+\tau_{c}+\varepsilon_{i t}
\end{aligned}
$$

where, for firm $i$, year $t$, and city $c, S A_{i t}$ represents the intensity of financial constraint, Pilotreat $_{i}$ is a dummy variable equal to one if the city in which firm $i$ is located was selected as a pilot low-carbon city, and zero otherwise; Post is a time dummy variable equal to one after a city was selected as a pilot low-carbon city (i.e., after 2012), and zero otherwise; $C V_{i t}$ represents the control variables, including Size, Lev, Growth, Cashflow, Dual, Executive, Roa, Top10, and Institute (see the Appendix for the definitions of the variables); and $\varphi_{t}, \omega_{i}$, and $\tau_{c}$ are the vectors of the year, firm, and city dummy variables, respectively, accounting for firm, year, and city fixed effects. To mitigate the influence of outliers, we winsorize all continuous variables at $1 \%$ and $99 \%$. All the regressions in this analysis cluster standard errors by firm, year, and city.

We focus on $\alpha_{3}$, the coefficient of Pilotreat ${ }_{i}^{*}$ Post $_{t}$, which indicates the net effect of low-carbon city pilot policies on corporate financial constraints before and after their implementation. To eliminate any potential endogeneity of nonrandom selection derived from the regulation per se, we adopt PSM with a DID methodology for a robustness test, following Q. Chen et al. (2012). We thus utilize a logistic regression model to match pilot cities to either the treatment group, with Pilotreat $_{i}=1$, or the control group, with Pilotreat $_{i}=0$. Simultaneously, we set the time dummy variable to denote those years after the implementation of the low-carbon city pilot, with Post $_{t}=1$, and Post $_{t}=0$ otherwise. We employ one-to-one nearest neighbor matching without replacement, including all firm-level control variables.

1. Financial constraints $(S A)$. To avoid endogeneity, we draw on the work of Hadlock and Pierce (2010) and select their size-age (SA) index as a measure of firms' financial constraints, because the SA index does not contain any endogenous financial variables. The higher the SA index, the greater the corporate financial constraints. Specifically, we first qualitatively classify each enterprise into one of five types of financial constraints, based on financial status. Second, we use an ordered probit model to estimate the SA index, with the following formula including firm size (Size) and firm age (Age):

$$
-0.737 \text { Size }+0.043 \text { Size }^{2}-0.04 \text { Age }
$$

2. Low-carbon city pilot regulation ( Pilotreat $_{i}$ ). We follow Cheng et al. (2019) and use Pilotreat $_{i}$ as a dummy variable to denote the treatment group. If the city where firm $i$ is located is selected as a pilot low-carbon city, Pilotreat $_{i}$ is equal to one, and zero otherwise. Given the small number of cities in the first pilot and the heavy bias of the cities in the third pilot, we construct this variable using the cities in the second low-carbon pilot. The registered address of each listed company is used to determine whether it is in a pilot city, according to the China Stock Market \& Accounting Research (CSMAR) database.

3. Control variables. Following Cui et al. (2018) and Cheng et al. (2019), we include the following firm-level variables that influence corporate financial constraints: size (Size), leverage (Lev), growth (Growth), cash flow (Cashflow), whether the chief executive officer is also the chair of the board (Dual), the ratio of executive shareholdings ( $E x$ ecutive), the return on assets (Roa), the top 10 shareholders' shareholdings (Top10), and the ratio of institutional investors (Institute). All the data for the control variables are obtained from the CSMAR database and defined in the Appendix.

\section{Empirical Results}

Table 1 reports the descriptive statistics of the regression variables. The mean financial constraint $(S A)$ is 3.73 , with a minimum and maximum of 3.252 and 4.117 , respectively, indicating large differences in financial constraint among the sampled firms. The mean and standard deviation of Pilotreat are 0.479 and 0.500 , respectively, indicating that nearly half of the sampled companies are located in a low-carbon city with high variance. The mean of $\mathrm{Pi}$ lotreat $_{i}{ }^{*}$ Post is 0.421 , indicating that $42.1 \%$ of the companies are affected by low-carbon city pilot regulation.

Table 2 reports the main results, which indicate that low-carbon city pilot regulation alleviates corporate financial constraints to some extent. Column (1) in Table 2 
Table 1. Descriptive statistics

\begin{tabular}{lcccccc}
\hline Variable & $\mathbf{N}$ & Mean & Sd & Min & Median & Max \\
\hline SA & 23004 & 3.730 & 0.225 & 3.252 & 3.738 & 4.117 \\
Pilotreat & 23004 & 0.479 & 0.500 & 0.000 & 0.000 & 1.000 \\
Post & 23004 & 0.700 & 0.458 & 0.000 & 1.000 & 1.000 \\
Post ${ }^{*}$ Pilotreat & 23004 & 0.421 & 0.494 & 0.000 & 0.000 & 1.000 \\
Size & 23004 & 22.104 & 1.299 & 19.046 & 21.926 & 26.687 \\
Lev & 23004 & 0.436 & 0.210 & 0.053 & 0.432 & 0.998 \\
Growth & 23004 & 0.205 & 0.525 & -0.708 & 0.117 & 3.963 \\
Cash & 23004 & 0.004 & 0.091 & -0.269 & 0.002 & 0.490 \\
Executive & 23004 & 0.091 & 0.165 & 0.000 & 0.000 & 0.657 \\
Dual & 23004 & 0.251 & 0.433 & 0.000 & 0.000 & 1.000 \\
Roa & 23004 & 0.036 & 0.061 & -0.401 & 0.035 & 0.204 \\
Top10 & 23004 & 57.793 & 15.498 & 22.020 & 58.760 & 95.240 \\
Turnover & 23004 & 0.616 & 0.435 & 0.026 & 0.515 & 2.539 \\
Institute & 23004 & 0.284 & 0.245 & 0.000 & 0.210 & 0.877 \\
\hline
\end{tabular}

Notes: Table 1 represents the descriptive statistics for all variables over the sample period for 2009-2018. Variables are all defined in Appendix. Pilotreat are stemmed from NDRC report; $S A$ and control variables are extracted from CSMAR database, but Institute is derived from RSSET database.

shows that the estimated coefficient of Pilotreat is significantly negative at the $1 \%$ level, the coefficient of Post is significantly positive at the $1 \%$ level, and the coefficient of the interaction Post*Pilotreat is significantly negative at the 1\% level. These results indicate that, compared with other companies, the intensity of the financial constraint of the pilot companies is significantly lower. Column (2) reports the regression results of PSM with a DID estimator. The coefficient of Post*Pilotreat is significantly negative at the 5\% level, which is consistent with the results of column (1). This is because pilot cities are more likely to be able to take advantage of a variety of green financing policies, including special funds for low-carbon development, subsidies for specific industries, loans at preferential interest rates, and tax reductions, which can alleviate potential enterprise financial constraints.

Table 3 reports the effects of firm heterogeneity on the negative correlation between low-carbon city pilot policies and financial constraints. Columns (1) and (2) report the grouped regression results of the low-carbon city pilot on the financial constraints of SOEs and non-SOEs. The results show that, compared with non-SOEs, the negative correlation between Post*Pilotreat and SA among SOEs is more significant, and the estimated coefficient of Post*Pilotreat is significant at the $1 \%$ level, while it is negatively nonsignificant and far smaller among non-SOEs. This result indicates that low-carbon city pilot policies ease the financial constraints of SOEs more significantly compared to those of non-SOEs.

The effects of macro-environmental policies on financial constraints can also be heterogeneous due to differences in ownership. First, SOEs and non-SOEs have different characteristics and advantages in terms of financing. On the one hand, SOEs shoulder important social responsibilities in their contribution to the local economy and are supported in various aspects, including fiscal subsidies, tax reductions and exemptions, and easier financing. On the other hand, there is an implicit link between SOEs and the government, and governments in low-carbon cities will give priority to implementing high-quality financial policies for and providing resources to SOEs. Non-SOEs, on the other hand, face fiercer market competition and their resource endowments are not as generous as those of SOEs, such that nonSOEs in the low-carbon city pilot did not benefit from any financial advantages.

Second, there are differences between manufacturing and non-manufacturing enterprises after the launch of the low-carbon city pilot. The carbon dioxide $\left(\mathrm{CO}_{2}\right)$ and sulfur dioxide $\left(\mathrm{SO}_{2}\right)$ emissions released by manufacturing companies were higher than those of their non-manufacturing counterparts. If manufacturing companies fail to meet minimum standards of environmental governance, they are subject to greater financial intervention than non-manufacturing enterprises. Therefore, the regulatory impact of the low-carbon city pilot on the financial constraints of manufacturing enterprises should be more significant.

Columns (3) and (4) in Table 3 report the grouped regression results of the effect of the low-carbon city pilot on the intensity of financial constraint. Compared with non-manufacturing enterprises, the negative correlation between Post*Pilotreat and $S A$ in manufacturing enterprises is more significant, and the coefficient of Post*Pilotreat is significantly negative at the $1 \%$ level, while it is positively nonsignificant among non-manufacturing enterprises. This result indicates that the negative impact of pilot policies on the intensity of financial constraint of manufacturing enterprises is more significant. The Chi-squared values of the coefficients between the two groups are 3.59 and 8.38, significant at the $10 \%$ and $1 \%$ levels, respectively, indicating that the estimated coefficients of Post*Pilotreat are significantly different between the two groups. 
Table 2. Preliminary and Robustness results

\begin{tabular}{|c|c|c|}
\hline \multirow[b]{3}{*}{ Variables } & \multicolumn{2}{|l|}{$S A$} \\
\hline & DID & DID+PSM \\
\hline & (1) & (2) \\
\hline \multirow[t]{2}{*}{ Pilotreat } & $-0.008^{* * *}$ & $-0.010^{*}$ \\
\hline & $(-3.248)$ & $(-1.650)$ \\
\hline \multirow[t]{2}{*}{ Post } & $0.333^{* * *}$ & $0.252^{* * *}$ \\
\hline & $(57.490)$ & (34.750) \\
\hline \multirow[t]{2}{*}{ Post ${ }^{*}$ Pilotreat } & $-0.008^{* * *}$ & $-0.011^{* *}$ \\
\hline & $(-2.587)$ & $(-2.205)$ \\
\hline \multirow[t]{2}{*}{ Size } & $0.024^{* * *}$ & $0.020^{* * *}$ \\
\hline & (5.535) & (2.898) \\
\hline \multirow[t]{2}{*}{ Lev } & -0.009 & 0.024 \\
\hline & $(-0.858)$ & (1.603) \\
\hline \multirow[t]{2}{*}{ Growth } & $0.009^{* * *}$ & $0.010^{* * *}$ \\
\hline & (7.719) & $(4.076)$ \\
\hline \multirow[t]{2}{*}{ Cash } & $0.027^{* * *}$ & 0.014 \\
\hline & (7.439) & (1.391) \\
\hline \multirow[t]{2}{*}{ Executive } & $-0.067^{* * *}$ & $-0.052^{* * *}$ \\
\hline & $(-6.801)$ & $(-3.043)$ \\
\hline \multirow[t]{2}{*}{ Dual } & $-0.006^{* *}$ & -0.004 \\
\hline & $(-2.168)$ & $(-1.004)$ \\
\hline \multirow[t]{2}{*}{ Roa } & $0.028^{* *}$ & 0.019 \\
\hline & $(2.126)$ & $(0.846)$ \\
\hline \multirow[t]{2}{*}{ Top10 } & $-0.001^{* * *}$ & -0.000 \\
\hline & $(-4.763)$ & $(-0.325)$ \\
\hline \multirow[t]{2}{*}{ Turnover } & 0.002 & 0.012 \\
\hline & $(0.372)$ & (1.349) \\
\hline \multirow[t]{2}{*}{ Institute } & $-0.042^{* * *}$ & $-0.036^{* * *}$ \\
\hline & $(-7.307)$ & $(-3.984)$ \\
\hline \multirow[t]{2}{*}{ Constant } & $3.035^{* * *}$ & $3.220^{* * *}$ \\
\hline & (30.443) & (19.936) \\
\hline Year/Firm/Region & Yes & Yes \\
\hline$N$ & 23004 & 5340 \\
\hline $\operatorname{Adj} R^{2}$ & 0.816 & 0.812 \\
\hline
\end{tabular}

Notes: This table reports the Preliminary and Robustness results. This table reports the results of multivariate DID and DID+PSM regressions explaining firm-level and controls for other aspects of "low-carbon cities" and for differences in regional effects. All specifications include year, firm and region fixed effects. Standard errors are robust to heteroskedasticity and are clustered at the firm level. All variables are defined in Appendix. Robust $t$-statistics are in parentheses. ${ }^{* * * * * *}$ and $*$ indicate statistical significance at the $1 \%, 5 \%$ and $10 \%$ level, respectively.

\section{Conclusion}

This paper investigates whether and how macro-environmental regulation impacts micro-enterprise financial behavior, enriching the literature regarding the economic consequence of macro-environmental regulation on microenterprises. This article also provides evidence on financial constraints from the perspective of macro-environmental regulation. The low-carbon city pilots provide a good setting to overcome endogeneity issues, and, using a DID methodology, we find that low-carbon city pilot regulation can diminish corporate financial constraints. Further analysis demonstrates that the negative relations between low- carbon city pilot regulation and firms' financial constraints are more significant in among SOEs and manufacturing enterprises. 
Table 3. Heterogeneity analyses results

\begin{tabular}{|c|c|c|c|c|}
\hline \multirow[b]{3}{*}{ Variables } & \multicolumn{4}{|c|}{$S A$} \\
\hline & Non_SOEs & SOES & Others & Manufacturing \\
\hline & (1) & (2) & (3) & (4) \\
\hline \multirow[t]{2}{*}{ Pilotreat } & -0.000 & $-0.012^{* * *}$ & $-0.012^{* * *}$ & -0.004 \\
\hline & $(-0.047)$ & $(-3.870)$ & $(-2.779)$ & $(-1.426)$ \\
\hline \multirow[t]{2}{*}{ Post } & $0.336^{* * *}$ & $0.332^{* * *}$ & $0.317^{* * *}$ & $0.337^{* * *}$ \\
\hline & (46.739) & (38.969) & (27.128) & $(60.162)$ \\
\hline \multirow[t]{2}{*}{ Post*Pilotreat } & -0.003 & $-0.012^{* * *}$ & 0.001 & $-0.009^{* * *}$ \\
\hline & $(-0.757)$ & $(-2.993)$ & $(0.236)$ & $(-2.950)$ \\
\hline \multirow[t]{2}{*}{ Size } & $0.037^{* * *}$ & 0.001 & 0.007 & $0.030^{* * *}$ \\
\hline & (7.061) & $(0.180)$ & (0.778) & (7.537) \\
\hline \multirow[t]{2}{*}{ Lev } & 0.018 & $-0.050^{* * *}$ & -0.012 & 0.000 \\
\hline & (1.441) & $(-3.170)$ & $(-0.579)$ & $(0.047)$ \\
\hline \multirow[t]{2}{*}{ Growth } & $0.010^{* * *}$ & $0.008^{* * *}$ & $0.009^{* * *}$ & $0.009^{* * *}$ \\
\hline & $(5.592)$ & (5.339) & $(4.668)$ & (6.133) \\
\hline \multirow[t]{2}{*}{ Cash } & $0.025^{* * *}$ & $0.020^{* * *}$ & $0.021^{* * *}$ & $0.024^{* * *}$ \\
\hline & $(5.890)$ & (3.071) & (3.238) & (5.898) \\
\hline \multirow[t]{2}{*}{ Executive } & $-0.045^{* * *}$ & $0.327^{* * *}$ & $-0.134^{* * *}$ & $-0.042^{* * *}$ \\
\hline & $(-4.978)$ & (3.366) & $(-5.000)$ & $(-4.457)$ \\
\hline \multirow[t]{2}{*}{ Dual } & -0.002 & $-0.009^{*}$ & $-0.012^{* *}$ & -0.002 \\
\hline & $(-0.949)$ & $(-1.855)$ & $(-2.081)$ & $(-1.028)$ \\
\hline \multirow[t]{2}{*}{ Roa } & $0.027^{* *}$ & 0.024 & 0.016 & $0.026^{* *}$ \\
\hline & (2.071) & (1.010) & $(0.612)$ & (1.967) \\
\hline \multirow[t]{2}{*}{ Top10 } & $-0.000^{* *}$ & $-0.000^{*}$ & $-0.001^{* *}$ & $-0.001^{* * *}$ \\
\hline & $(-2.341)$ & $(-1.752)$ & $(-2.068)$ & $(-4.782)$ \\
\hline \multirow[t]{2}{*}{ Turnover } & 0.001 & -0.001 & -0.008 & 0.008 \\
\hline & (0.149) & $(-0.117)$ & $(-0.824)$ & (1.357) \\
\hline \multirow[t]{2}{*}{ Institute } & $-0.044^{* * *}$ & $-0.019^{* *}$ & $-0.056^{* * *}$ & $-0.023^{* * *}$ \\
\hline & $(-5.626)$ & $(-2.158)$ & $(-5.397)$ & $(-3.883)$ \\
\hline \multirow[t]{2}{*}{ Constant } & $2.689^{* * *}$ & $3.606^{* * *}$ & $0.003^{* *}$ & 0.001 \\
\hline & (23.087) & (22.773) & $(2.355)$ & (1.529) \\
\hline Year/Firm/Region & Yes & Yes & Yes & Yes \\
\hline$N$ & 12463 & 10541 & 8254 & 14750 \\
\hline$A d j \_R^{2}$ & 0.858 & 0.791 & 0.722 & 0.871 \\
\hline $\mathrm{Chi}^{2}$ & \multicolumn{2}{|c|}{3.59} & \multicolumn{2}{|c|}{8.38} \\
\hline Prob $>$ Chi2 & \multicolumn{2}{|c|}{0.0582} & \multicolumn{2}{|c|}{0.0038} \\
\hline
\end{tabular}

Notes: This table reports the Heterogeneity analyses results. This table reports the results of influence of the firm heterogeneity on the relation between "low-carbon cities" and corporate financial constraints with the DID method and controls for other aspects of "low-carbon cities" and for differences in regional effects. All specifications include year, firm and region fixed effects. Standard errors are robust to heteroskedasticity and are clustered at the firm level. All variables are defined in Appendix. Robust t-statistics are in parentheses. ******* and *indicate statistical significance at the $1 \%, 5 \%$ and $10 \%$ level, respectively. 


\section{References}

Aghion, P., Cai, J., Dewatripont, M., Du, L., Harrison, A., \& Legros, P. (2015). Industrial Policy and Competition. American Economic Journal: Macroeconomics, 7(4), 1-32.

Chen, D., Li, O. Z., \& Xin, F. (2017). Five-year plans, China finance and their consequences. China Journal of Accounting Research, 10(3), 189-230.

Chen, Q., Chen, X., Schipper, K., Xu, Y., \& Xue, J. (2012). The sensitivity of corporate cash holdings to corporate governance. Review of Financial Studies, 25(12), 3610-3644. https://doi.org/10.1093/rfs/hhs09 $\underline{9}$

Cheng, J. H., Yi, J., Dai, S., \& Yan, X. (2019). Can lowcarbon city construction facilitate green growth? evidence from China's pilot low-carbon city initiative. Journal of Cleaner Production, 231, 1158-1170.

Cui, J., Zhang, J., \& Yang, Z. (2018). Carbon pricing induces innovation: Evidence from China's regional carbon market pilots. AEA Papers and Proceedings, 108, 453-457.

Eaton, J., \& Grossman, G. M. (1986). Optimal Trade and Industrial Policy under Oligopoly. The Quarterly Journal of Economics, 101(2), 383-406.
Hadlock, C. J., \& Pierce, J. R. (2010). New evidence on measuring financial constraints: Moving beyond the KZ index. Review of Financial Studies, 23(5), 1909-1940. https://doi.org/10.1093/rfs/hhq009

Kollmann, R., Roeger, W., \& Veld, J. I. (2012). Fiscal Policy in a Financial Crisis: Standard Policy vs. Bank Rescue Measure. American Economic Review, 102, 77-81.

Song, H., Sun, Y. J., \& Chen, D. K. (2019). Assessment of the effect of government air pollution control regulation: Empirical evidence from "low-carbon city” construction in China (in Chinese). Management World, 35(06), 95-108+195.

Stiglitz, J. E., \& Weiss, A. (1981). Credit Relationing in Markets with Imperfect Information. American Economic Review, 71, 393-410.

Zhang, H. (2020). Can low-carbon city construction reduce carbon emissions? Evidence from a Quasinatural experiment (in Chinese). Business Management Journal, 42(06), 25-41. 
Appendix: Variable definitions

\begin{tabular}{|c|c|c|}
\hline Variable & Variable definitions & Source \\
\hline SA & Financial constraints, measured by $-0.737 \cdot$ Size+0.043·Size ${ }^{2}-0.04 \cdot$ Age & $\begin{array}{l}\text { CSMAR } \\
\text { database }\end{array}$ \\
\hline Pilotreat & $\begin{array}{l}\text { A dummy variable of the treatment group, if c city where i firm is located is selected as a pilot of "low- } \\
\text { carbon city", Pilotreati=1, otherwise 0; }\end{array}$ & $\begin{array}{l}\text { CSMAR } \\
\text { database }\end{array}$ \\
\hline Post & A time dummy variable, the year after obtaining a "low-carbon city" pilot, Post $t_{t}=1$, otherwise Post $t_{t}=0$. & $\begin{array}{l}\text { CSMAR } \\
\text { database }\end{array}$ \\
\hline $\begin{array}{l}\text { Post* } \\
\text { Pilotreat }\end{array}$ & The interaction term of Pilotreat and Post. & $\begin{array}{l}\text { CSMAR } \\
\text { database }\end{array}$ \\
\hline Size & $\begin{array}{l}\text { Firm size, measured by the natural logarithm of the book value of total assets (in RMB) at the end of } \\
\text { the year. }\end{array}$ & $\begin{array}{l}\text { CSMAR } \\
\text { database }\end{array}$ \\
\hline Lev & Leverage, total debt divided by total assets at the end of the year. & $\begin{array}{l}\text { CSMAR } \\
\text { database }\end{array}$ \\
\hline Growth & Sale growth, measured by the change of sales divided by sales in last year & $\begin{array}{l}\text { CSMAR } \\
\text { database }\end{array}$ \\
\hline Executive & $\begin{array}{l}\text { Shareholding's ratio of executive, measured by the number of shares held by senior executives / total } \\
\text { number of common shares of the firm }\end{array}$ & $\begin{array}{l}\text { CSMAR } \\
\text { database }\end{array}$ \\
\hline Dual & Indicator variable equals to " 1 ", if the CEO is also the chair of board, otherwise " 0 ". & $\begin{array}{l}\text { CSMAR } \\
\text { database }\end{array}$ \\
\hline Top10 & The shareholding ratio of the company's top ten shareholders & $\begin{array}{l}\text { CSMAR } \\
\text { database }\end{array}$ \\
\hline Roa & Operating income divided by total assets at the end of the year. & $\begin{array}{l}\text { CSMAR } \\
\text { database }\end{array}$ \\
\hline Institute & $\begin{array}{l}\text { Institutional ownership, the fraction of shares owned by non-SAMA legal entities, such as mutual } \\
\text { funds, insurance companies, or other firms. }\end{array}$ & $\begin{array}{l}\text { RESSET } \\
\text { database }\end{array}$ \\
\hline
\end{tabular}

